\title{
34. A PALEOCLIMATIC AND PALEOCEANOGRAPHIC RECORD OF THE PALEOGENE IN THE CENTRAL SOUTH ATLANTIC (LEG 73, SITES 522, 523, AND 524) ${ }^{1}$
}

\author{
H. Oberhänsli, J. McKenzie, and M. Toumarkine, Geologisches Institut, Eidgenössische Technische Hochschule \\ Zürich, CH-8092 Zürich, Switzerland \\ and \\ H. Weissert, Geologisches Institut, University of Basel, Bernoullianum, CH-4056 Basel, Switzerland ${ }^{2}$
}

\begin{abstract}
We carried out oxygen and carbon isotope studies on monospecific foraminifer samples from DSDP Sites 522, 523, and 524 of Leg 73 in the central South Atlantic Ocean. The oxygen isotope ratios show a warming of 2 to $3^{\circ} \mathrm{C}$ in bottom water and $5^{\circ} \mathrm{C}$ in surface water during the Paleocene and early Eocene. The carbon isotope values indicate strong upwelling during the early Eocene. The $1 \%$ increase in the $\delta^{18} \mathrm{O}$ values of benthic and planktonic foraminifers at Site 523 in the later middle Eocene we ascribe to changes in the pattern of the evaporation and precipitation. The changes may be due to the worldwide Lutetian transgression. The oxygen ratios for the benthic and planktonic foraminifers indicate a cooling at the Eocene/Oligocene transition. The maximum temperature drop $\left(5^{\circ} \mathrm{C}\right.$ for benthic and $3^{\circ} \mathrm{C}$ for planktonic foraminifers) is recorded slightly beyond the Eocene/Oligocene boundary and took place over an interval of about $100,000 \mathrm{yr}$. The pattern of currents in the Southern Hemisphere was mainly structured by a precursor of the subtropical convergence during the Paleocene to late Eocene. The cooling at the Eocene/Oligocene transition led to drastic changes in the circulation pattern, and a precursor of the Antarctic convergence evolved.
\end{abstract}

\section{INTRODUCTION}

The last decade has greatly advanced our knowledge of the history of the Cenozoic ocean. Cores recovered from deep sea drilling during different DSDP cruises in the Pacific, Atlantic, Antarctic, and Indian oceans have shed light on the evolution of worldwide climate and on oceanographic changes. Cooperation between paleontologist, sedimentologist, and isotope geochemist has permitted the development of a fairly detailed idea of the evolution of global circulation patterns and climate based on faunal and geochemical changes during the Mesozoic and Tertiary.

The Paleogene represents only one interval in the observed worldwide cooling period that began in the Late Cretaceous and culminated in the late Neogene glaciation. The most distinguishing characteristic of the Paleogene is the establishment of the psychrosphere, which occurred during the late Eocene and earliest Oligocene. This phenomenon was first described by Benson (1975). Another important oceanographic event during the early part of the Cenozoic was the change from a predominantly equatorial to a circumantarctic circulation pattern (Berggren and Hollister, 1977).

In the Pacific, Douglas and Savin $(1973,1975)$, Haq (1976), Haq, Lohmann, et al. (1977), Kennett (1977), Savin et al. (1975), and Shackleton and Kennett (1975a, b) provided basic information on the Paleogene paleontology and isotope stratigraphy. In the Atlantic, Boersma and Shackleton (1977, 1978), Haq, Premoli Silva, et al. (1977), Perch-Nielsen (1977), Toumarkine (1978), Vergnaud Grazzini and Lointier (1980), and Vergnaud Graz-

\footnotetext{
${ }^{1}$ Hsü, K. J., LaBrecque, J. L., et al., Init. Repts. DSDP, 73: Washington (U.S. Govt. Printing Office). This chapter is Contribution No. 209 of the Experimental Geology Laboratory, ETH Zürich.

2 Present address: Geologisches Institut, ETH Z, CH-8092 Zürich, Switzerland.
}

zini et al. (1978) contributed to an understanding of the Paleogene climatic and oceanographic changes. In the Indian Ocean, mainly McGowran (1979) and Kennett (1978) have recorded the faunal changes during the Paleogene.

In this study, stable isotope analyses were carried out on different Paleogene planktonic and benthic monospecific samples of foraminifers from Sites 522, 523, and 524 on Leg 73 in the South Atlantic (Fig. 1). The purpose of these analyses was to understand the geochemical and climatic changes in the eastern South Atlantic during the Paleogene. Sediments recovered at these sites provide almost complete coverage of the $\mathrm{Pa}$ -

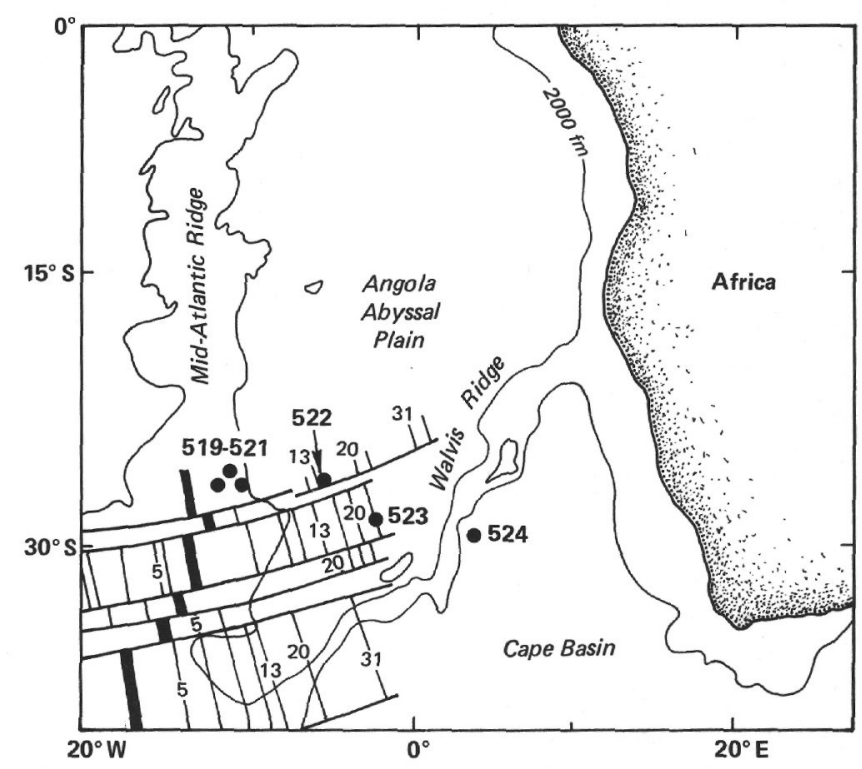

Figure 1. Location of the Leg 73 drill sites. Small numbers identify magnetic anomalies. 
leogene with sufficient biostratigraphic and paleomagnetic control. Hence, we could trace the initiation and duration of the climatic and oceanographic changes, as well as their intensity, from the Paleocene to the Eocene/Oligocene boundary.

\section{STRATIGRAPHY}

The three studied sites (Fig. 1) were drilled along a transect between 25 and $30^{\circ}$ South latitude. Sites 522 and 523 are situated in the southern Angola Abyssal Plain, and Site 524 is on the southeastern flank of the Walvis Ridge. At Site 524, the Paleocene sediments contain mainly turbiditic bryozoan fragments and foraminifers in volcaniclastic sandstones, indicating neritic conditions on parts of the Walvis Ridge during the early to late Paleocene. In the uppermost Paleocene the detrital influence diminished suddenly and pelagic sedimentation became established. In the late Paleocene to early Eocene, chert layers indicate a brief interval of siliceous planktonic activity. This time interval was uniquely recovered at Site 524. At Sites 522 and 523, during the middle and late Eocene as well as in Oligocene, mainly nannofossil oozes with a fairly constant $\mathrm{CaCO}_{3}$ content $(80-90 \%)$ accumulated. At Site 523 , several layers of marls up to $80 \mathrm{~cm}$ thick are intercalated in the nannofossil ooze sequence between 100 and $145 \mathrm{~m}$. Foraminifer-nannofossil oozes were only observed at the Eocene/ Oligocene transition at Site 522. At Site 523, some foraminifer sand intercalations up to several centimeters thick (Cores 41-50) indicate periodical detrital influences from the Walvis Ridge. This reworking was noted in the middle Eocene and also in the Oligocene. The oldest sediments ( 50 m.y.) of Site 523 were deposited at a depth of about $2300 \mathrm{~m}$ (site chapters, this vol.). By the Eocene/Oligocene boundary, this site had subsided to a depth of $3400 \mathrm{~m}$. At Site 522 the investigated interval (late Eocene-early Oligocene) was sedimented at a depth between 2500 and $3000 \mathrm{~m}$.

\section{ANALYTICAL METHODS}

For the isotopic record, monospecific planktonic and benthic foraminifer samples were picked. Sample weight was between 0.1 and 0.5 $\mathrm{mg}$. The foraminifer samples were slightly broken and then cleaned by ultrasonic treatment to remove adhering particles from chamber cavities. Before isotope processing, these cleaned samples were finely crushed and afterwards roasted in vacuo at $400^{\circ} \mathrm{C}$ for $30 \mathrm{~min}$. The carbon dioxide was released by reaction with $100 \%$ orthophosphoric acid at $50^{\circ} \mathrm{C}$. The isotopic composition of the gas was measured by a triple collector mass spectrometer, Micromas $903 \mathrm{C}$ at the Geological Institute of the ETH in Zürich. The isotope ratios are reported in the $\delta$ notation as per mill deviation from the PDB standard. For the oxygen and carbon isotope ratios the analytical precision is $\mp 0.1 \%$.

\section{RESULTS AND SOME REMARKS ON PALEONTOLOGICAL VARIABLES}

Planktonic and benthic foraminifers are valuable tools for recording surface and bottom water conditions in the isotope composition of their tests. The following monospecific planktonic foraminifer samples provided information on geochemical and temperature changes in surface water masses during the Paleogene.

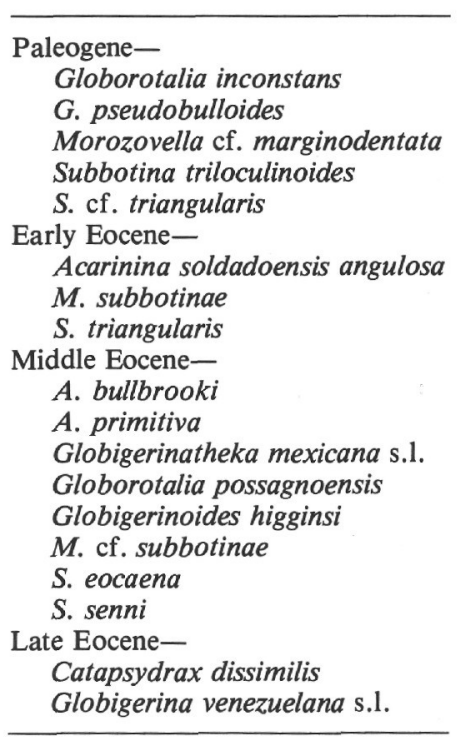

Changes in bottom water properties could be quantified by isotope ratio measurements of the following monospecific benthic foraminifer samples:

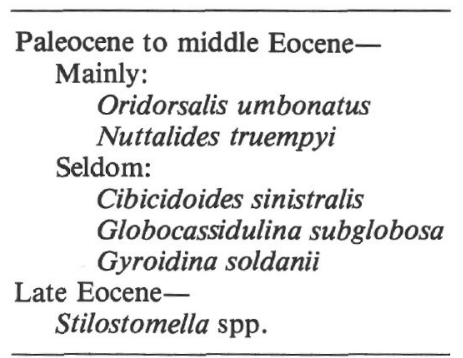

A continuous record of the same species throughout the Paleogene could not always be realized because the composition of the assemblages often changed. Thus, at Site 522 Stilostomella spp. were used as the bottom water recorder because only this genus could provide a continuous record across the Eocene/Oligocene boundary. The oxygen and carbon isotope values of benthic and planktonic foraminifers are plotted in Figures 2 to 4 and listed in Tables 1 to 3 . Investigations on recent and fossil planktonic foraminifers demonstrate that different species live or have lived at different water depths (Berger, 1969; Hecht and Savin, 1972; and Douglas and Savin, 1978). This depth stratification can be traced at least back to the Late Cretaceous. Douglas and Savin (1978) found that from Paleogene species some Acarinina and Morozovella spp. yield lower $\delta^{18} \mathrm{O}$ values than Subbotina spp. These species were restricted to surface and/or intermediate water depth, whereas turborotalids were preferentially intermediate to deep dwellers. According to the results of Douglas and Savin (1978), the $\delta^{18} \mathrm{O}$ values of Acarinina and Morozovella spp. are 0.5 to $0.6 \%$ lighter than those of Subbotina spp., while the $\delta^{13} \mathrm{C}$ values are generally about $1.4 \%$ heavier than those of Subbotina spp. Further, the $\delta^{18} \mathrm{O}$ values of Catapsydrax dissimilis are 0.5 to $0.6 \%$ heavier than the oxygen isotope ratio of different Globigerina and Globoquad- 
Table 1. Oxygen and carbon isotope data for Site 524. Isotope values are per mill and are reported with respect to PDB.

\begin{tabular}{|c|c|c|c|c|c|c|c|c|c|c|c|c|c|c|c|c|c|}
\hline \multirow{2}{*}{$\begin{array}{c}\text { Sample } \\
\text { (interval in } \mathrm{cm} \text { ) }\end{array}$} & \multirow{2}{*}{$\begin{array}{l}\text { Core } \\
\text { depth } \\
\text { (m) }\end{array}$} & \multicolumn{2}{|c|}{$\begin{array}{c}\text { Subbotina } \\
\text { spp. }\end{array}$} & \multicolumn{2}{|c|}{$\begin{array}{l}\text { Morozovella } \\
\text { spp. }\end{array}$} & \multicolumn{2}{|c|}{$\begin{array}{c}\text { Acarinina } \\
\text { spp. }\end{array}$} & \multicolumn{2}{|c|}{$\begin{array}{l}\text { Chiloguem- } \\
\text { belina } \\
\text { spp. }\end{array}$} & \multicolumn{2}{|c|}{$\begin{array}{c}\text { Globorotalia } \\
\text { pseudo- } \\
\text { bulloides }\end{array}$} & \multicolumn{2}{|c|}{$\begin{array}{c}\text { Gavelinella } \\
\text { beccarii- } \\
\text { formis }\end{array}$} & \multicolumn{2}{|c|}{$\begin{array}{c}\text { Nuttalides } \\
\text { truempyi }\end{array}$} & \multicolumn{2}{|c|}{$\begin{array}{l}\text { Oridorsalis } \\
\text { umbonatus }\end{array}$} \\
\hline & & $\delta^{18} \mathrm{O}$ & $\delta^{13} \mathrm{C}$ & $\delta^{18} \mathrm{O}$ & $\delta^{13} \mathrm{C}$ & $\delta^{18} \mathrm{O}$ & $\overline{\delta^{13} \mathrm{C}}$ & $\delta^{18} \mathrm{O}$ & $\overline{\delta^{13} \mathrm{C}}$ & $\delta^{18} \mathrm{O}$ & $\overline{\delta^{13} \mathrm{C}}$ & $\delta^{18} \mathrm{O}$ & $\overline{\delta^{13} \mathrm{C}}$ & $\delta^{18} \mathrm{O}$ & $\delta^{13} \mathrm{C}$ & $\delta^{18} \mathrm{O}$ & $\delta^{13} \mathrm{C}$ \\
\hline $524 B-3-2,45-47$ & 9.5 & -0.74 & $1.11^{\mathrm{a}}$ & -1.26 & $2.37^{\mathrm{d}}$ & -1.22 & $2.02^{\mathrm{g}}$ & -1.18 & $\begin{array}{l}0.54^{\mathrm{i}} \\
0.69^{\mathrm{j}}\end{array}$ & & & & & -0.95 & -0.32 & -1.57 & -0.63 \\
\hline $\begin{array}{l}5-2,135-137 \\
7-3,12-14\end{array}$ & $\begin{array}{l}18.9 \\
28.1\end{array}$ & $\begin{array}{l}-0.57 \\
-0.66\end{array}$ & $\begin{array}{l}1.11^{\mathrm{b}} \\
1.71^{\mathrm{a}}\end{array}$ & $\begin{array}{l}-1.33 \\
-1.53 \\
-1.14\end{array}$ & $\begin{array}{l}2.30^{\mathrm{d}} \\
3.31^{\mathrm{e}} \\
2.59^{\mathrm{f}}\end{array}$ & -1.08 & $2.30^{\mathrm{h}}$ & -0.88 & & & & & & $\begin{array}{l}-0.73 \\
-0.53\end{array}$ & $\begin{array}{l}0.37 \\
1.00\end{array}$ & -0.35 & -0.06 \\
\hline $\begin{array}{r}524-9-3,25-27 \\
11-3,31-33\end{array}$ & $\begin{array}{r}98.3 \\
117.3\end{array}$ & $\begin{array}{l}-0.45 \\
-0.17\end{array}$ & $\begin{array}{l}1.92^{\mathrm{b}} \\
2.06^{\mathrm{c}}\end{array}$ & & & & & & & -0.57 & 1.70 & -0.46 & 1.08 & & & & \\
\hline $\begin{array}{l}\text { a } \text { Subbotina spp. } \\
\text { b } S \text {. triangularis. } \\
\text { c } S \text {. triloculinoides. } \\
\text { d } M \text {. subbotinae. } \\
\text { e } M \text {. cf. marginode }\end{array}$ & ata. & $\begin{array}{l}\text { M. veld } \\
\text { A. sold } \\
\text { A. sold } \\
\text { C. subc } \\
\text { C. wilc }\end{array}$ & $\begin{array}{l}\text { coensis. } \\
\text { doensis } \\
\text { doensis. } \\
\text { lindrica. } \\
\text { xensis. }\end{array}$ & gulosc & & & & & & & & & & & & & \\
\hline
\end{tabular}

Table 2. Oxygen and carbon isotope data for Hole 523. Isotope values are per mill and are reported with respect to PDB.

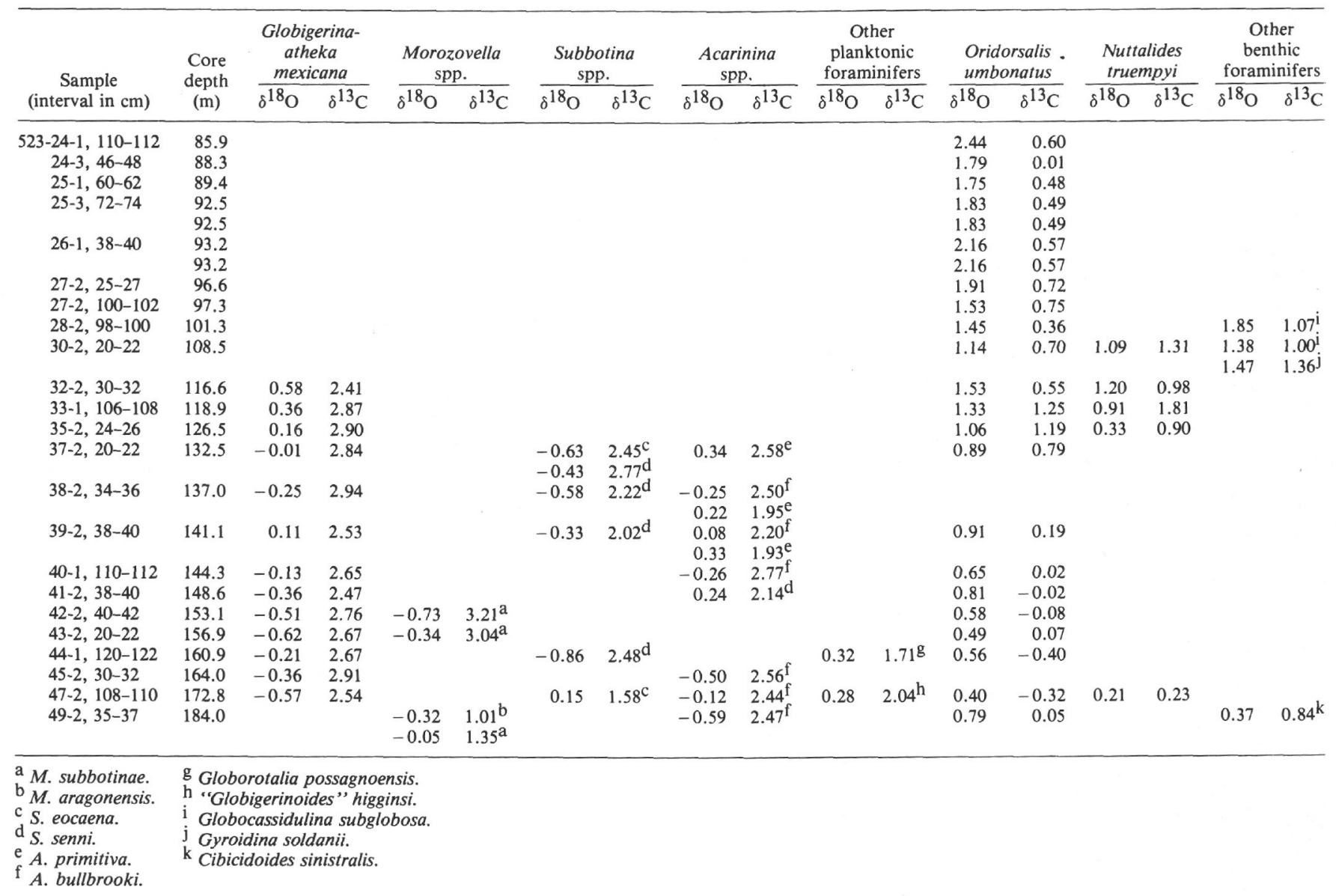

rina spp. From these results we conclude that $C$. dissimilis lived in intermediate to deeper water, while Globigerina venezuelana s.l. was an intermediate to surface dweller.

Isotope investigations of different recent planktonic and benthic foraminifer species showed that the calcite of most species is not formed under equilibrium conditions with the environment (Woodruff et al., 1980; Vincent et al., 1981). These authors found that the calcite of the test deviates from equilibrium values by a speciesspecific factor. Therefore, isotope values of different species can often not be compared directly, and absolute gradient estimates between surface and bottom water are questionable. If we try to draw parallels between our data and those of other investigations (Boersma and Shackleton, 1977; Douglas and Savin, 1973, 1975; Shackleton and Kennett, 1975a), difficulties arise, because often only $\delta^{18} \mathrm{O}$ and $\delta^{13} \mathrm{C}$ compositions of mixed benthic and planktonic assemblages are available.

\section{DISCUSSION}

The oxygen isotope composition of planktonic and benthic foraminifers monitor changes in not only temperature but also in the water mass properties of both 
Table 3. Oxygen and carbon isotope data for Hole 522. Isotope values are per mill and are reported with respect to PDB.

\begin{tabular}{|c|c|c|c|c|c|c|c|c|c|}
\hline \multirow{2}{*}{$\begin{array}{c}\text { Sample } \\
\text { (interval in } \mathrm{cm} \text { ) }\end{array}$} & \multirow{2}{*}{$\begin{array}{l}\text { Core } \\
\text { depth } \\
\text { (m) }\end{array}$} & \multicolumn{2}{|c|}{$\begin{array}{c}\text { Globigerina } \\
\text { venezuelana } \\
\text { s.l. } \\
\end{array}$} & \multicolumn{2}{|c|}{$\begin{array}{c}\text { Catapsydrax } \\
\text { dissimilis }\end{array}$} & \multicolumn{2}{|c|}{$\begin{array}{c}\text { Stilostomella } \\
\text { spp. }\end{array}$} & \multicolumn{2}{|c|}{$\begin{array}{l}\text { Oridorsalis } \\
\text { umbonatus }\end{array}$} \\
\hline & & $\delta^{18} \mathrm{O}$ & $\overline{\delta^{13} \mathrm{C}}$ & $\delta^{18} \mathrm{O}$ & $\delta^{13} \mathrm{C}$ & $\delta^{180}$ & ${ }_{\delta^{13} \mathrm{C}}$ & $\delta^{18} \mathrm{O}$ & $\delta^{13} \mathrm{C}$ \\
\hline $522-31-2,34-36$ & 119.2 & & & & & & & 1.88 & 0.08 \\
\hline $34-1,45-47$ & 130.2 & & & 1.65 & 1.68 & 2.30 & 1.07 & & \\
\hline $34-1,95-97$ & 130.7 & 1.05 & 2.13 & 1.73 & 2.07 & 2.35 & 1.31 & & \\
\hline $34-1,135-137$ & 131.1 & & & 1.91 & 1.86 & 2.30 & 1.29 & & \\
\hline $34-2,24-26$ & 131.4 & & & 1.82 & 2.09 & 2.32 & 1.01 & & \\
\hline $34-2,40-42$ & 131.6 & & & & & & & 2.30 & 0.84 \\
\hline $34-2,60-62$ & 131.8 & 1.13 & 2.16 & 1.70 & 1.87 & 2.33 & 1.20 & & \\
\hline $34-2,100-102$ & 132.2 & & & 2.09 & 2.25 & 2.15 & 1.30 & & \\
\hline $34-2,139-141$ & $132-6$ & & & 1.62 & 2.20 & 2.33 & 1.36 & & \\
\hline $34-3,43-45$ & 133.1 & 1.28 & 2.25 & 2.26 & 2.20 & 2.45 & 1.32 & & \\
\hline $34-3,93-95$ & 133.6 & & & 1.80 & 2.09 & 2.10 & 1.45 & & \\
\hline $35-1,41-43$ & 134.1 & & & 1.66 & 1.84 & 1.87 & 0.84 & & \\
\hline $35-1,80-82$ & 134.5 & 0.72 & 2.05 & 0.90 & 1.81 & 1.38 & 1.05 & & \\
\hline $35-1,130-132$ & 135.0 & & & 1.12 & 1.74 & 1.40 & 0.87 & & \\
\hline $35-2,12-14$ & 135.3 & 0.77 & 2.24 & 1.26 & 1.77 & 1.56 & 0.88 & & \\
\hline $35-2,53-55$ & 135.7 & 0.75 & 2.04 & 1.35 & 1.89 & & & & \\
\hline $35-2,94-96$ & 136.1 & 0.55 & 1.97 & 1.23 & 1.95 & 1.70 & 0.59 & & \\
\hline $36-1,30-32$ & 136.5 & & & 1.00 & 1.57 & 1.60 & 1.01 & & \\
\hline $36-1,79-81$ & 137.0 & 0.43 & 1.80 & 0.86 & 1.78 & 1.59 & 1.05 & & \\
\hline $36-1,130-132$ & 137.5 & 0.84 & 1.99 & 1.28 & 1.70 & 1.43 & 0.95 & & \\
\hline $36-2,22-24$ & 137.9 & 0.47 & 1.81 & 1.05 & 1.40 & 1.13 & 0.77 & & \\
\hline $36-2,68-70$ & 138.4 & & & 1.16 & 1.70 & 1.35 & 0.95 & & \\
\hline $36-2,120-122$ & 138.9 & & & 0.87 & 1.43 & & & & \\
\hline $36-3,6-8$ & 139.3 & & & 1.15 & 1.17 & 1.25 & 0.05 & & \\
\hline $36-3,43-45$ & 139.6 & 0.66 & 1.42 & 0.87 & 1.43 & 1.21 & 0.27 & & \\
\hline $37-1,55-57$ & 140.3 & 0.57 & 1.24 & 1.04 & 1.28 & & & & \\
\hline $37-1,70-72$ & 140.4 & & & & & & & 0.84 & 0.11 \\
\hline $37-1,93-95$ & 140.6 & 0.64 & 1.55 & 1.06 & 1.49 & 1.18 & 0.52 & & \\
\hline $37-1,138-140$ & 141.1 & & & 1.14 & 1.32 & 1.05 & 0.66 & & \\
\hline $37-2,12-14$ & 141.3 & 0.76 & 1.67 & 1.11 & 1.75 & 1.03 & 0.48 & & \\
\hline $37-2,33-35$ & 141.5 & & & 1.06 & 1.37 & 1.06 & 0.51 & & \\
\hline $37-2,83-85$ & 142.0 & & & 1.11 & 1.45 & 1.19 & 0.65 & & \\
\hline $37-2,133-135$ & 142.5 & & & 1.13 & 1.39 & 1.12 & 0.96 & & \\
\hline $37-3,63-65$ & 143.3 & 0.63 & 1.52 & 0.93 & 1.61 & 1.58 & 0.78 & & \\
\hline $38-1,24-26$ & 143.9 & 0.54 & 1.47 & 1.00 & 1.43 & & & & \\
\hline $38-1,70-72$ & 144.4 & 0.63 & 1.50 & 0.94 & 1.75 & 1.25 & 0.47 & & \\
\hline $38-1,124-126$ & 144.9 & & & 0.94 & 1.27 & 1.00 & 0.24 & & \\
\hline $38-2,20-22$ & 145.4 & 0.62 & 1.71 & 1.03 & 1.57 & 1.06 & 0.36 & & \\
\hline $38-2,70-72$ & 145.9 & & & 0.90 & 1.56 & 1.38 & 0.77 & & \\
\hline $38-2,119-121$ & 146.4 & & & 1.42 & 1.54 & 1.36 & 0.65 & & \\
\hline $39-3,10-12$ & 146.8 & & & 1.05 & 1.58 & 1.66 & 0.73 & & \\
\hline
\end{tabular}

the surface and the bottom water. The oxygen isotope composition of the seawater is dependent on changes in salinity; changes in salinity are related to changes in global ice volume and modifications in the fresh water flowing into the ocean. Interpretations of the oxygen ratios of foraminifers may be meaningless without additional information from paleontological and sedimentological investigations, because temperature increases may counterbalance a salinity increase in the $\delta^{18} \mathrm{O}$ record (e.g., a temperature increase results in lighter $\delta^{18} \mathrm{O}$ values of foraminifers, whereas a higher salinity environment modifies the $\delta^{18} \mathrm{O}$ ratio in the skeletal calcite towards heavier values). Carbon isotope ratios, which depend on the isotopic composition of the dissolved carbonate in the seawater, record fluctuations in biological productivity. This study demonstrates the relationship between changes in $\delta^{18} \mathrm{O}$ and $\delta^{13} \mathrm{C}$ values, climatic modifications, and changes in the circulation pattern. To a certain extent, climate and circulation are influenced by the ocean/continent configuration.

Paleobathymetric reconstructions at the Cretaceous/ Tertiary boundary by Sclater et al. (1977) show that by this time the South Atlantic was already open to deep water at the southern end. In addition, the Vema Gap was deep enough to allow the passage of bottom water into the northern basins of the South Atlantic, although the Walvis Ridge and the Rio Grande Rise can be considered a barrier to an efficient exchange of bottom wa- ter between the south and north. During the Paleocene and Eocene, both morphological heights subsided, but only in the Oligocene did the Walvis Ridge reach a depth below $3000 \mathrm{~m}$. By the late Paleocene, the northern South Atlantic was probably also open to the north, allowing deep and shallow water to penetrate to and from the North Atlantic (Sclater et al., 1977). During the Paleocene (65-55 Ma), Australia and Antarctica remained joined (Weissel et al., 1977). In the early Eocene ( $\sim 55 \mathrm{Ma}$ ), Australia began to drift northward, but the continents remained connected by the South Tasman Rise. Only by the late Eocene (40 Ma) had a shallow water connection developed over the South Tasman Rise and allowed circulation between the southern Pacific and Indian oceans. This initial circumantarctic flow, the increasing isolation of the Antarctic continent, and some other as yet unknown factors initiated the Antarctic glaciation in the later Paleogene (Margolis et al., 1977; Shackleton and Kennett, 1975a; Keigwin, 1980).

The isotope stratigraphy from the studied sites of Leg 73 in the northern Cape Basin and the southern Angola Basin show three well-defined intervals from the early Paleocene to the early Oligocene. Each interval will be discussed separately.

\section{Late Paleocene to Early Eocene (Nannofossil Zones NP4-NP5, NP9-NP12?)}

In the northern Cape Basin (Site 524, Fig. 2) the $\delta^{18} \mathrm{O}$ values of Subbotina spp. and Nuttalides truempyi decrease by 0.6 and $0.3 \%$ from the late Paleocene to the early Eocene. The $\delta^{18} \mathrm{O}$ values for planktonic and benthic foraminifers are almost the same. The decrease in the oxygen isotope ratio indicates a warming by about $2{ }^{\circ} \mathrm{C}$ in the surface water during the NP4 to NP5 time and by 1 to $2^{\circ} \mathrm{C}$ in the bottom and surface water layer during the NP9 to NP12? time. In the North Atlantic, the oxygen isotope data from Hole 400A (Vergnaud Grazzini et al., 1978) reveal the same trend as observed in the investigated sites of the eastern South Atlantic. In the North Atlantic, the $\delta^{18} \mathrm{O}$ values of Subbotina indicate a warming by $6^{\circ} \mathrm{C}$ in the surface water from NP3 to NP11, whereas the $\delta^{18} \mathrm{O}$ values of mixed Oridorsalis and Nuttalides assemblages document a warming in bottom water by about $4^{\circ} \mathrm{C}$ from NP9 to NP11. These oxygen isotope changes in planktonic and benthic foraminifers, coeval in the northern and southern Atlantic, show an excellent time coincidence with migrations of flora and fauna in the Atlantic, which Haq, Premoli Silva, et al. (1977) interpreted as climatic fluctuations. According to these authors, this excursion of low latitude assemblages (Ericsonia subpertusa and Toweius craticulus assemblages) toward higher latitudes indicates a temperature increase between 57 and 47 Ma.

Observations of flora, fauna, and geochemistry in the Southern Hemisphere indicate the occurrence of similar climatic changes within this time interval. Isotopic measurements in surface water planktonic foraminifers from the subpolar Site 277 (Shackleton and Kennett, 1975a) also indicate a warming of 2 to $3^{\circ} \mathrm{C}$ at the transition from the late Paleocene to the early Eocene. A temperature decrease may be interpreted from the oxygen isotope ratios 


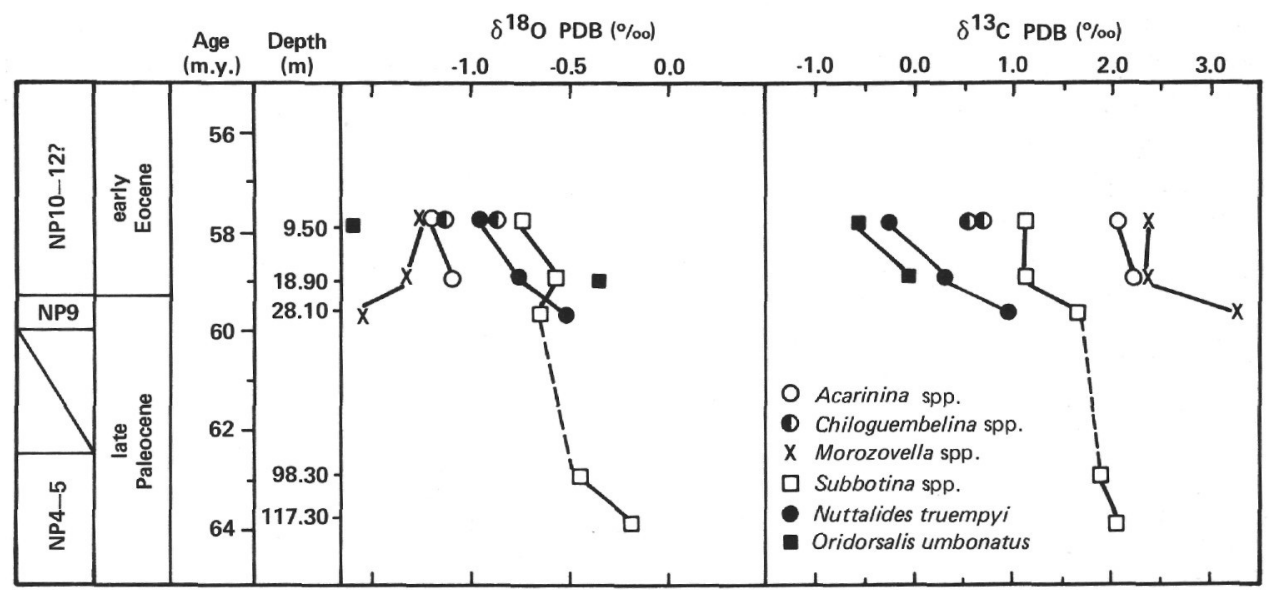

Figure 2. Late Paleocene to early Eocene stable isotope stratigraphy, based on monospecific foraminifer samples from Site 524.

of the benthic foraminifers from this site. This interpretation is based on $\delta^{18} \mathrm{O}$ measurements of mixed benthic assemblages, however, so we cannot directly compare the data with ours.

Investigations of flora and fauna by Kemp (1978, 1981), Kennett (1978), and McGowran (1979) in the early Paleocene sediments of Australia and Antarctica as well as in the southern Indian and Pacific oceans gave evidence of relatively cool conditions. On the continents, a cool moist climate prevailed; in the oceans, planktonic assemblages of cosmopolitan type and low diversity dominated (Kemp, 1978; Kennett, 1978). In the late $\mathrm{Pa}$ leocene and early Eocene, floral and faunal assemblages reflected warmer conditions in the oceans and on the continents, although a cooler reversal seems to be documented by an increased occurrence of Chiasmolithus near the top of Paleocene (Edwards and Perch-Nielsen, 1975). Kemp $(1978,1981)$ interpreted the early Eocene floral spectra in Australia as typical rain forest vegetation adapted to a warm temperate climate, a climate that even shows local resemblances to a tropical climate.

In the investigated samples of Site 524, we did not find a $\delta^{18} \mathrm{O}$ gradient between planktonic intermediate dwellers and benthic foraminifers. This might be partly due to the species-specific disequilibrium values. In the Paleocene oceans a latitudinal and, hence, vertical temperature gradient existed but was not very pronounced (Douglas and Woodruff, in press). Therefore the $\delta^{18} \mathrm{O}$ values of benthic foraminifers should be at least slightly heavier than those of planktonic foraminifers, since Site 524 may well have been at a depth of a few thousand meters at that time (see site chapters, this vol.). The minor difference in the $\delta^{18} \mathrm{O}$ values beween planktonic and benthic foraminifers could point to a low salinity component ( ${ }^{16} \mathrm{O}$ enrichment) in the bottom water of the Cape Basin. In the Paleocene and early Eocene, widespread rain forests indicate a major rain belt in the southern trade and subpolar belts (Kemp, 1978, 1981). Such a climatic barrier would change not only the vegetation but may also have lowered the salinity of the seawater over vast areas in the ocean. By this time the sea- water probably had salinity characteristics similar to those we observe today in the surface water south of the subtropical convergence (Dietrich, 1963). In the earlier Paleogene, this lower salinity seawater, which was also cooler than the adjacent subtropical surface water masses, covered higher mid- and high-latitude realms of the southern Indian and southern Atlantic oceans. We assume that this surface water sank along a precursor of the subtropical convergence and provided the bottom water in the South Atlantic basins, inasmuch as the Cape Basin was already open toward the south (Sclater et al., 1977). In the Paleogene, the convergence and divergence pattern was probably less differentiated than it is today because latitudinal temperature gradients were low and circumantarctic currents did not yet exist. We believe therefore that by this time only one significant convergence existed in the southern oceans.

The $\delta^{13} \mathrm{C}$ values of Nuttalides truempyi decrease by $1.2 \%$ from the late Paleocene to the early Eocene. The $\delta^{13} \mathrm{C}$ values of Subbotina spp. and Morozovella spp. decrease by 0.5 and $1 \%$ respectively in the late Paleocene and stagnate for both planktonic foraminifers in the early Eocene. The $\delta^{13} \mathrm{C}$ values of the morozovellids and acarinids (which are both considered to be surface dwellers) were rather high from the late Paleocene to the early Eocene. Of course, this discussion assumes that the $\delta^{13} \mathrm{C}$ compositions of the $\Sigma \mathrm{CO}_{2}$ in surface water was strongly influenced by biological processes. At Site 524, several chert layers that date from the late Paleocene to the early Eocene were found. This sediment type indicates an increase in siliceous planktonic activity and may be attributed to transient upwelling currents. In this time interval siliceous intercalations were not restricted to this area but were also described for instance from Indian Ocean sites (Fisher et al., 1974; Simpson et al., 1974). In addition to this evidence for high siliceous planktonic activity, calcareous nannofossil and dinoflagellate diversity increased during the late Paleocene and early Eocene (Haq, 1973; Bujak and Williams, 1979). Further, Davies and Worsley (1981) reported increasing $\mathrm{CaCO}_{3}$ accumulation rates. We conclude, therefore, that the 
relatively heavy $\delta^{13} \mathrm{C}$ values of the surface planktonic foraminifers were due to biological activity, because ${ }^{12} \mathrm{C}$ is preferentially enriched in organic matter, and hence the dissolved carbonate in the surface layer became depleted in ${ }^{12} \mathrm{C}$ (Deuser and Hunt, 1969).

The $\delta^{13} \mathrm{C}$ gradient between surface dwellers and subsurface (Subbotina spp.) and bottom inhabitants is very pronounced. We consider the low $\delta^{13} \mathrm{C}$ values for benthic foraminifers further proof that the source area of the bottom water in the Cape Basin was located in the Southern Ocean adjacent to the Australo-Antarctic continent during the late Paleogene and early Eocene. Since, as mentioned earlier, these continents were covered with rain forests (Kemp, 1978, 1981) and the climate was temperate and humid up to high latitudes, the weathering of organic material and the erosion of continents were favored. Thus, the plant and soil supply transferred from the continents to the ocean grew, and the $\delta^{13} \mathrm{C}_{\mathrm{\Sigma CO}_{2}}$ in the adjacent ocean declined considerably (Shackleton, 1977). Hence, the $\delta^{13} \mathrm{C}$ value of the bottom water was already light. Further, during the time of high fertility in the ocean, the $\delta^{13} \mathrm{C}$ gradient between the surface and the bottom water probably became even more pronounced because of the accelerated oxidation of organic matter.

The low $\delta^{13} \mathrm{C}$ values of the intermediate dweller $S u b$ botina may be further evidence for upwelling activity (besides the cherty intercalations). Such a current would have brought bottom water with low $\delta^{13} \mathrm{C}$ values toward the surface and have influenced the carbon isotope ratio of the intermediate and deep dwelling planktonic foraminifers significantly.

\section{Middle Eocene (Nannofossil Zones NP15-NP17, Site 523)}

The comparable $\delta^{18} \mathrm{O}$ values of Subbotina spp. in the early and middle Eocene (Figs. 2 and 3 ) indicate that during this time interval the climatic conditions were relatively stable at this latitude. Isotope data from sites in the North Atlantic (Vergnaud Grazzini et al., 1978) and the western South Atlantic (Boersma and Shackleton, 1977) suggest a similar interpretation. Nannofossil and foraminiferal associations and their latitude distribution during this time interval led to the same conclusion (Haq, Lohmann, et al., 1977; and Haq, Premoli Silva, et al., 1977). According to their observations in the Atlantic, the climate was warm up to the higher latitudes $\left(60^{\circ} \mathrm{N}\right.$ and S) from the late Paleocene (NP9) to the early middle Eocene (NP15).

The $\delta^{18} \mathrm{O}$ values of $N$. truempyi and $O$. umbonatus increased by $1.1 \%$ from the early to the middle Eocene and indicate a cooling in the bottom water. This temperature difference may be due to the paleodepth of the Angola Basin (Site 523), which was greater than that of the Cape Basin (Site 524). On the other hand, it may be related to the lower temperatures observed at the higher latitudes (Kemp, 1981), the source area of the South Atlantic bottom water. Investigations of flora from Australia and Antarctica indicate a cooling at the beginning of the middle Eocene. The rain forests with tropical resemblances of early Eocene age became rereplaced by the floral associations of cool temperate climates. According to Kemp $(1978,1981)$, forests of the latter type are at present unknown. Therefore, no sound conclusions on the extent of the cooling can be drawn. McGowran (1979) reported comparable data. He described typical larger tropical foraminifers from the middle latitudes in the Indian Ocean in the later early Eocene, which withdrew to lower latitudes during earlier middle Eocene. After this cooling at higher latitudes, which also affected the bottom water at the middle latitudes, climatic conditions seems to stabilize for the rest of the early middle Eocene (Table 2 and Fig. 3, Sample 52349-2, 35-37 cm-Sample 523-42-2, 40-42 cm, NP15NP15/16).

Only in the later middle Eocene (NP16-NP17) did planktonic and benthic foraminifer $\delta^{18} \mathrm{O}$ values increase further (by about 1\%o). As Boersma and Shackleton (1977) and Vergnaud Grazzini et al. (1978) could prove, this increase is not confined to the investigated area. These authors found a similar change in the western South Atlantic as well as in the North Atlantic. Isotope investigations by Shackleton and Kennett (1975a) on the Campbell Plateau in the southwest Pacific and by Douglas and Savin (1973) in the northern Pacific showed the same development in the Pacific as in the Atlantic. But the changes observed in the Pacific are not isochronous, which could partly be due to the incomplete core recovery. In the tropical Pacific (Site 167, Douglas and Savin, 1973) no significant changes in bottom water $\delta^{18} \mathrm{O}$ composition are recorded to the base of Foraminifer Zone $\mathrm{P} 14-\mathrm{P} 15$. Then the oxygen isotope ratio of benthic foraminifers increases continuously by about $1 \%$ up to P17. In the southwest Pacific an increase by $1 \%$ is documented from P13 to P14. In the western South Atlantic, the $\delta^{18} \mathrm{O}$ values of benthic foraminifers increase from P14 to P16 and the values for planktonic foraminifers increase from P12 to P13 by about $1.2 \%$. A $\delta^{18} \mathrm{O}$ plot of benthic and planktonic foraminifers from Hole 400A in the North Atlantic shows a decrease by $1.2 \%$ from P12 to P16 (Vergnaud Grazzini et al., 1978). The direct comparison of isotope data from different oceans is somewhat difficult because often only mixed faunal assemblages were measured. Nevertheless, some conclusions can be drawn. The comparable increase of the $\delta^{18} \mathrm{O}$ values and the time coincidence point to an unusual event which may have produced the oxygen isotope changes in the different oceans. Possible causes of such a change could be a worldwide cooling and/or a widespread change in the pattern of evaporation and precipitation.

Investigations on the distribution of calcareous plankton in the Atlantic by Haq, Premoli Silva, et al. (1977) indicate a change in the interval from 46 to $43 \mathrm{Ma}$ (NP16). These authors explained the observed changes in the faunal assemblages by a drop in temperature. According to our isotope data this would mean that surface and bottom temperatures diminished, even in the warm temperate zone, by $5^{\circ} \mathrm{C}$. Such a temperature decrease should have enormous climatic consequence and could lead to growing polar ice or at least to a significant glaciation in mountain chains on continents. Present knowledge gives no indication of a major mid- 


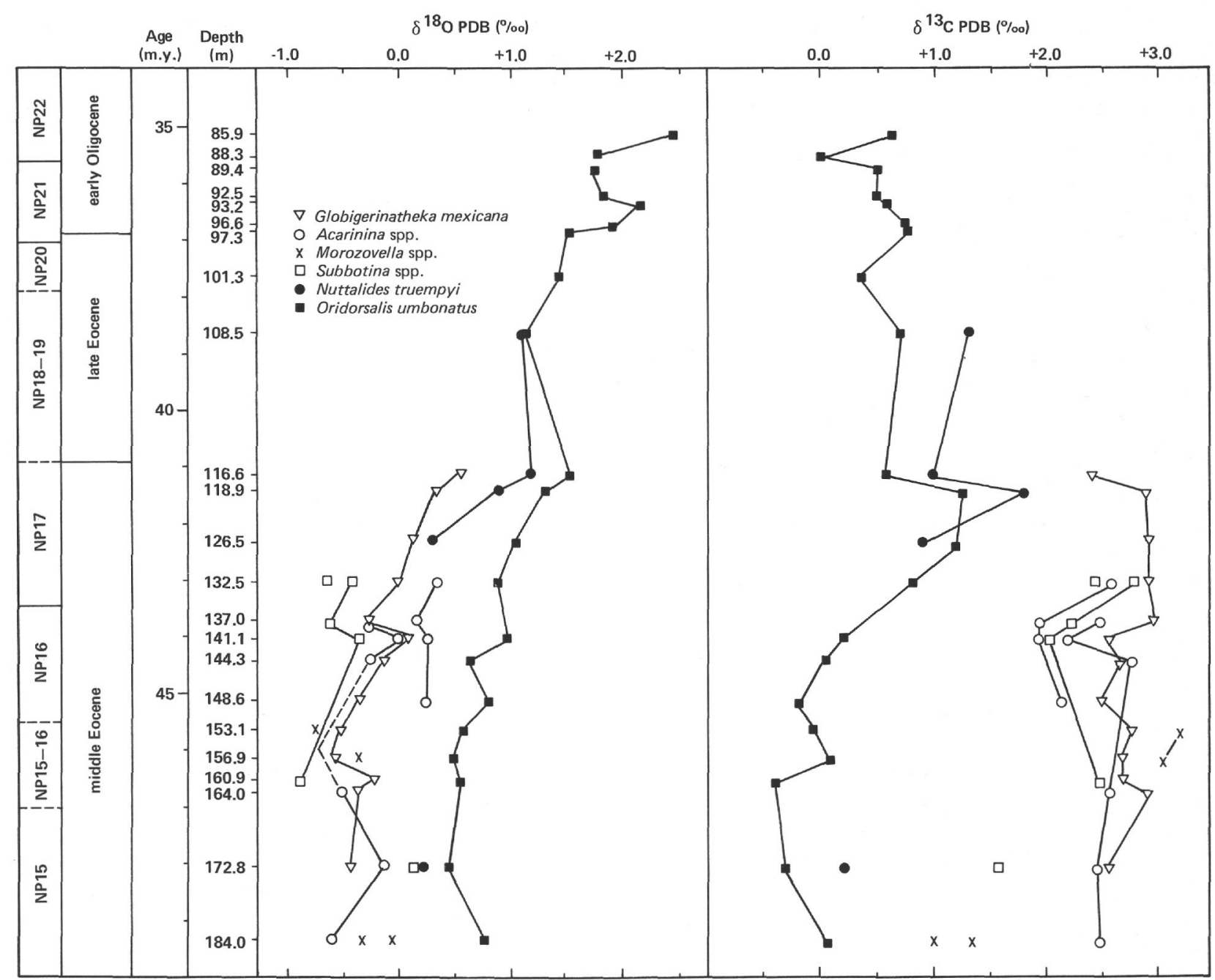

Figure 3. Middle Eocene to early Oligocene stable isotope stratigraphy, based on monospecific foraminifer samples from Site 523.

dle Eocene polar glaciation that reached sea level (Kennett, 1977). In mountain chains, similarly, no prominent glaciation is known.

Paleobotanic and paleontological data from different continents cast doubt on a drastic cooling of surface seawater in the lower and middle latitudes during this time interval. Wolfe (1972) gives data on paratropic rain forest assemblages (Ravenian flora) from the Alaskan middle Eocene. In Europe, the climate was significantly warmer than at present until the early Oligocene (Hochuli, 1978). Schwarzbach (1974) observed palm trees at latitudes up to $55^{\circ} \mathrm{N}$, tropical trees and beetles in central Germany, and crocodiles in southern England until the late Eocene. Vast brown coal deposits are reported from the German middle Eocene (Schwarzbach, 1974). Proof of a generally warm Eocene period also exists from the Southern Hemisphere. Kemp $(1978,1981)$ described temperate rain forests in Australia of late middle Eocene and late Eocene age. McGowran (1979) observed a protrusion of larger tropical foraminifers toward the south in the Indian Ocean during the latest middle Eocene to the late Eocene. Indications of a warmer climate were also found in Patagonia (Volkheimer, 1971). The $10^{\circ} \mathrm{C}$ isotherm during the Paleocene and Eocene lay approxi- mately $1500 \mathrm{~km}$ farther south than at present. All these observations clearly contradict a significant global cooling earlier than the Oligocene.

Investigations of Paleogene sediments of the Indian Ocean and of Australia (McGowran, 1979) show that during the late middle Eocene, deposition on continental margins, especially of the northern and eastern Indian Ocean, is characterized by an isochron transgression. According to him, this transgression was not restricted to this area but can be connected with the classical Lutetian transgression (P12-P13, 46 Ma). Such an event could influence the pattern of evaporation and precipitation and would, therefore, also affect the oxygen isotope composition of the seawater. A transgression favors evaporation in shallow areas, and thus the seawater is depleted in ${ }^{16} \mathrm{O}$ over large shelf areas. We believe that the faunal changes observed by Haq, Premoli Silva, et al. (1977) were caused by modifications in the salinity pattern of the surface water rather than only by significant temperature changes.

In the South Angola Basin, the surface water mass properties were probably influenced by a precursor of the Agulhas Current (Frakes and Kemp, 1973) which was derived at this time from shallow areas in the West- 
ern Indian Ocean. In this source area evaporation, favored by the transgression, also changed the $\delta^{18} \mathrm{O}$ composition of the surface water, which we found in the later middle Eocene foraminifers of Site 523. Bottom water was probably derived at this time from shallow water areas, as had been the case during the late Paleocene and early Eocene (in, for example, the shelf areas associated with the Australian and Antarctic continent; this will be discussed later).

The $\delta^{18} \mathrm{O}$ values of Subbotina spp. are slightly lighter than those of Acarinina and Morozovella spp. According to Douglas and Savin (1978), Subbotina dwells at intermediate water depths, whereas Acarinina and Morozovella typically inhabit surface water. In the late Paleocene and early Eocene, the depth ranking based on the $\delta^{18} \mathrm{O}$ values of these species is consistent with the observations made by these authors. The virtually reversed depth ranking during the middle Eocene might be explained by a pronounced thermosaline stratification in the uppermost 100 to $200 \mathrm{~m}$ of the surface water layer. But this interpretation is highly hypothetical and needs further testing.

According to Sclater et al. (1977), the subsidence of the Walvis Ridge was so far advanced that communication between the sites south (524) and north of the ridge (523) began to occur in the middle Eocene. The comparable $\delta^{13} \mathrm{C}$ values of benthic and planktonic foraminifers (Figs. 2 and 3 ) indicate that the connection between the two basins was not restricted to the surface water mass but existed also at deeper levels. The unchanged surface values from the early to early middle Eocene suggest that the productivity pattern of the surface water mass did not change significantly. The comparable carbon isotope ratio of $O$. umbonatus also indicates that the bottom water source areas remained the same. However, the $\delta^{13} \mathrm{C}$ values of the intermediate dwellers are compelling evidence for a different evolution. Early middle Eocene Subbotina spp. (Sample 523-47-2, 108$110 \mathrm{~cm}$ ) reveal higher values $(1.6 \%$ ) than those of early Eocene Subbotina spp. (1.1\%). In Sample 523-44-1, 120$122 \mathrm{~cm}$, the $\delta^{13} \mathrm{C}$ values of the Subbotina spp. are similar to those of Globigerinatheka mexicana $(2.5 \%)$. This excursion is probably due to the decreasing upwelling component and may be linked to the progressive subsidence of the Walvis Ridge.

The $\delta^{13} \mathrm{C}$ increase in the bottom water at NP16 time (Fig. 3) follows the $\delta^{18} \mathrm{O}$ enrichment observed in the surface and bottom water. During this period, the $\delta^{13} \mathrm{C}$ values of the planktonic foraminifers did not change. They indicate unaltered biological activity in the surface water. The modifications in the bottom water $\delta^{13} \mathrm{C}$ composition can be explained in two ways; either the bottom water was formed in another area or conditions changed significantly in the source area. We favor the latter interpretation. As pointed out earlier, later middle Eocene sedimentation was imprinted by a worldwide transgression that is also well documented in Australia (McGowran, 1979). In enlarged shelf areas more nutrients are tapped, and thus biological productivity increases in general during transgressions. As a consequence, the $\delta^{13} \mathrm{C}$ values of this seawater will be depleted in ${ }^{12} \mathrm{C}$. Thus, during the middle Eocene, as during the late Paleocene and early Eocene, the bottom water of the Angola Basin may still have been produced adjacent to the Australo-Antarctic continent, although geochemical conditions had changed significantly.

\section{Late Eocene to Early Oligocene (Nannofossil Zones NP18-NP21, Sites 522 and 523)}

The Leg 73 results indicate that the late Eocene and the transition from the Eocene to the Oligocene are best documented in the Angola Basin (Site 522, Fig. 4). At Site 523 the only observations are a few samples of $O$. umbonatus (Fig. 3); they display the same trend as at Site 522. At Site 522 the earlier late Eocene (NP18-NP20) is characterized by relatively stable $\delta^{18} \mathrm{O}$ and $\delta^{13} \mathrm{C}$ values for planktonic and benthic foraminifers, an indication that conditions were stable. Only in the uppermost part of NP20 did the $\delta^{18} \mathrm{O}$ values of the planktonic foraminifers Catapsydrax dissimilis and Globigerina venezuelana s.l. and the benthic foraminifers (Stilostomella spp.) increase steplike by more than $0.5 \% \circ\left(3^{\circ} \mathrm{C}\right)$ and $1 \%$ $\left(6^{\circ} \mathrm{C}\right)$, respectively. The maximum increase is recorded slightly beyond the Eocene/Oligocene boundary. The pronounced changes in oxygen isotope ratios are most probably influenced by the initial cooling observed mainly at the higher latitudes (Shackleton and Kennett, 1975a).

In the southwest Pacific and in the equatorial Pacific only minor changes in the $\delta^{18} \mathrm{O}$ composition of planktonic and benthic foraminifers are recorded in the late Eocene (Shackleton and Kennett, 1975a, b; Savin et al., 1975). These authors also reported a significant shift $(1 \%)$ toward heavier values, especially in benthic foraminifers from the early Oligocene. Paleontological investigations in the Atlantic and the Southern Ocean (Haq, Premoli Silva, et al., 1977; Kemp, 1978, 1981; Kennett, 1978) displayed the same trend. Since the cooling in high latitudes from the early to middle Eocene, a vegetation adapted to a cool temperature climate (Kemp, 1981) was prevalent in coastal areas of southern Australia and Antarctica. However, the temperature was still not low enough by the late Eocene to promote a significant glaciation on the Antarctic continent (Kennett, 1977; Margolis et al., 1977). Only in the late Oligocene do ice rafted sediments point to a south polar glaciation that had reached sea level (Hayes and Frakes, 1975). Therefore, we conclude that the oxygen isotope changes observed in the Angola Basin may not be influenced by modifications in the volume of polar ice at the Eocene/ Oligocene transition. Rather, we believe that temperature decreases in the middle and high latitudes produced this oxygen isotope shift.

This sharply pointed temperature drop at the Eocene/ Oligocene boundary coincides with a continental plate configuration that allowed significant surface circulation between the Pacific and Indian oceans over the Tasman Rise and thus resulted in the isolation of Antarctica (Weissel et al., 1977). This new continent configuration in the Southern Hemisphere may have affected the oceanic as well as the atmospheric circulation pattern and probably favored the establishment of a precursor of 


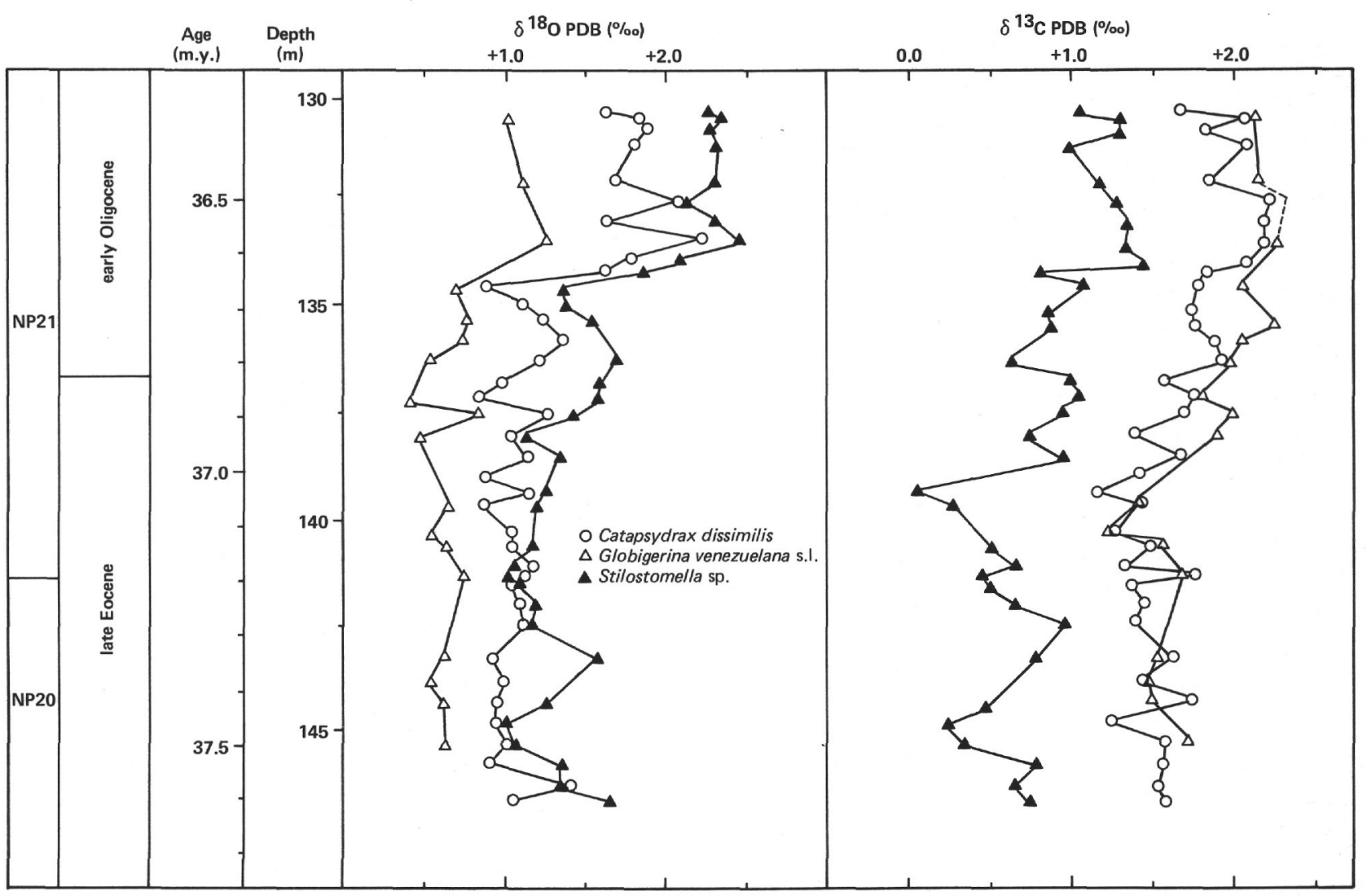

Figure 4. Late Eocene to early Oligocene stable isotope stratigraphy, based on monospecific foraminifer samples from Site 522.

the Antarctic convergence. A proper circumantarctic flow pattern did not exist at this time, inasmuch as the Drake Passage was not sufficiently open (Barker and Burrell, 1976). This would mean that the bottom water source area became restricted to a very narrow area adjacent to the Antarctic continent and was confined to the north by the precursor of the Antarctic convergence. Such a new oceanographic boundary would also favor cooling in the high latitudes, because, in addition to other as yet unknown factors, heat exchange between the subtropical and higher latitudes would be drastically reduced.

The depletion in ${ }^{12} \mathrm{C}$ by about $0.5 \%$ for both benthic and planktonic foraminifers at the Eocene/Oligocene transition is difficult to explain. Shackleton (1977) noticed that glacial samples have a lighter $\delta^{13} \mathrm{C}$ than samples formed during a less glaciated time interval. In this study, when we observed an isotopic cooling, the $\delta^{13} \mathrm{C}$ values of benthic foraminifers became heavier. According to Shackleton's observation this could mean that the temperature drop did not lead to significant glaciation during the transition from the Eocene to the early Oligocene. However, the increasing $\delta^{13} \mathrm{C}$ values for benthic foraminifers could indicate that bottom water was formed close to the Antarctic continent, where the weathering of soil and plant tissue diminished with the cooling. The parallel increase of the $\delta^{13} \mathrm{C}$ values in subsurface planktonic foraminifers. (C. dissimilis and G. venezuelana s.1.) can be explained by the decreased productivity in surface water at this latitude and, therefore, the retarded decay of organic matter. Low productivity and accumulation rates during this time interval sustain such an interpretation (Davies and Worsley, 1981; Kennett, 1977). An increased dissolution rate, also an effect of the cooling, may have strengthened to a certain extent the ${ }^{12} \mathrm{C}$ depletion (Luz and Shackleton, 1975). The bottom water of the early Oligocene did not have the water mass properties of recent Antarctic Bottom Water, which displays low $\delta^{13} \mathrm{C}$ values (Kroopnick, 1980a, b). Nevertheless, significant changes in bottom water properties are evident, because Benson (1975) and Douglas and Woodruff (in press) reported a worldwide major crisis in deep sea benthic foraminifers at the Eocene/Oligocene boundary. There may be other reasons for this crisis besides temperature changes.

\section{CONCLUSIONS}

Stable isotope investigations on three DSDP sites in the South Atlantic led to the following conclusions:

\section{Paleocene to Early Eocene}

1. Oxygen isotope ratios in the midlatitude Site 524 in the northern Cape Basin revealed a warming of about $5^{\circ} \mathrm{C}$ in the surface water and 2 to $3^{\circ} \mathrm{C}$ in bottom water from the early Paleocene to the early Eocene.

2. Relatively low oxygen and carbon isotope values of Oridorsalis umbonatus and Nuttalides truempyi point to a lower salinity source area for the bottom water. The low carbon isotope ratios of these benthic foraminifers indicate that the bottom water had a considerable $\mathrm{CO}_{2}$ 
component of organic origin. By this time a broad rain belt existed in the trade belt and vast areas of the southern continents were covered with rain forests (Kemp, 1978, 1981). We conclude, therefore, that the South Atlantic Bottom Water was generated in the southern oceans adjacent to the Australo-Antarctic continent.

3. We interpret the remarkably low $\delta^{13} \mathrm{C}$ values of the intermediate planktonic dwellers as an indicator for upwelling activities which were probably also favored by the morphological high of the Walvis Ridge.

\section{Middle Eocene}

1. In the early middle Eocene (NP15) the gradually increasing $\delta^{13} \mathrm{C}$ values of intermediate planktonic dwellers may indicate diminishing upwelling currents probably due to progressed subsidence of the Walvis Ridge.

2. The increasing $\delta^{18} \mathrm{O}$ and $\delta^{13} \mathrm{C}$ values of planktonic and benthic foraminifers from NP16 to NP17 we would not interpret as a cooling, but we would link it to the worldwide observed Lutetian transgression. Transgression favors evaporation, especially in shallow water realms, and therefore ${ }^{18} \mathrm{O}$ is enriched in seawater. With transgressive conditions, more nutrients are trapped on shelf areas, and biological activities may increase there. Inasmuch as both factors influence the isotopic composition towards heavier values, we can assume that both surface and bottom water isotopic composition are influenced in their source area by this transgression. The surface water was derived during the middle Eocene from shallow areas adjacent to the Indian Ocean and was brought to the southern Atlantic by a proto-Agulhas Current. The source area of the bottom water had probably not changed since the early Eocene; therefore, bottom water was formed adjacent to the Australo-Antarctic continent.

\section{Late Eocene to Early Oligocene}

Oxygen isotope ratios of benthic and planktonic foraminifers indicate a temperature decrease by about $5^{\circ} \mathrm{C}$ in bottom layers and by about $3^{\circ} \mathrm{C}$ in surface water layers from the very late Eocene to the earliest Oligocene. The maximum decrease is recorded slightly beyond the Eocene/Oligocene boundary and occurred within approximately $100,000 \mathrm{yr}$. The temperature drop coincides with the isolation of Antarctica from Australia. Thus, circulation may be significantly changed, and a precursor of the Antarctic convergence was probably established. This convergence restricted the bottom water source area to a narrow realm adjacent to the Antarctic.

\section{ACKNOWLEDGMENTS}

We would like to thank Dr. R. Poore. He provided picked samples of the Holes 523 and 524. Drs. J. P. Beckmann and M. Spindler are acknowledged for their review of the paper. Our work was supported by the Swiss National Science Foundation Grant No. 5.521.330.787/9.

\section{REFERENCES}

Barker, P. F., and Burrell, J., 1976. The opening of the Drake Passage. Proc. Joint Oceanographic Assembly, Food and Agricultural Organization of the United Nations: Rome, pp. 1-103.

Benson, R. H., 1975. The origin of the psychrosphere as recorded in changes of deep-sea ostracode assemblages. Lethaia, 8:69-83.
Berger, W. H., 1969. Ecologic pattern of living planktonic foraminifera. Deep Sea Res., 16:1-24.

Berggren, W. A., and Hollister, C. D., 1977. Plate tectonics and paleocirculation-commotion in the ocean. Tectonophysics, 38: 11-48.

Boersma, A., and Shackleton, N. J., 1977. Tertiary oxygen and carbon isotope stratigraphy, Site 357 (Mid Latitude South Atlantic). In Supko, P. R., Perch-Nielsen, K., et al., Init. Repts. DSDP, 39: Washington (U.S. Govt. Printing Office), 911-924. 1978. Oxygen and carbon isotope record through the Oligocene, DSDP Site 366, Equatorial Atlantic. In Lancelot, Y. Seibold, E., et al., Init. Repts. DSDP, 41: Washington (U.S. Govt. Printing Office), 957-962.

Bujak, J. P., and Williams, G. L., 1979. Dinoflagellate diversity through time. Mar. Micropaleontol., 4:1-12.

Davies, T., and Worsley, T., 1981. Paleoenvironmental implications of oceanic carbonate sedimentation rates. In Douglas, R. G., Winterer, E. L., and Warme, J. (Eds.), Spec. Publ., Soc. Econ. Paleontol. Mineral., 31:169-179.

Deuser, W. G., and Hunt, J. M., 1969. Stable isotope ratios of dissolved inorganic carbon in the Atlantic. Deep Sea Res., 16:221-225.

Dietrich, G., 1963. General Oceanography: New York (Intersci. Publ).

Douglas, R. G., and Savin, S. M., 1973. Oxygen and carbon isotope analyses of Cretaceous and Tertiary foraminifera from the central North Pacific. In Winterer, E. L., Ewing, J. I., et al., Init. Repts. DSDP, 17: Washington (U.S. Govt. Printing Office), 591-605. 1975. Oxygen and carbon isotope analyses of Tertiary and Cretaceous microfossils from Shatsky Rise and other sites in the North Pacific Ocean. In Larson, R. G., Moberly, R., et al., Init. Repts. DSDP, 32: Washington (U.S. Govt. Printing Office), 509-520.

, 1978. Oxygen isotopic evidence for the depth stratification of Tertiary and Cretaceous planktic foraminifera. Marine Micropaleontol., 3:175-196.

Douglas, R. G., and Woodruff, F., in press. Deep sea benthic foraminifera. Deep Sea Res.

Edwards, A. R., and Perch-Nielsen, K., 1975. Calcareous nannofossils from the southern Southwest Pacific, Deep Sea Drilling Project, Leg 29. In Kennett, J. P. Houtz, R. E., et al., Init. Repts. $D S D P, 29$ : Washington (U.S. Govt. Printing Office), 469-539.

Fisher, R. L., Bunce, E. T., et al., 1974. Init. Repts. DSDP, 24: Washington (U.S. Govt. Printing Office).

Frakes, L. A., and Kemp, E. M., 1973. Paleogene continental positions and evolutions of climate. In Tarling, D. H., and Runcorn, S. K. (Eds.), Implications of Continental Drift to the Earth Sciences (Vol. 1): London (Academic Press), 539-559.

Haq, B. U., 1973. Transgressions, climatic change and diversity of calcareous nannoplankton. Mar. Geol., 15:25-30.

1976. Coccoliths in cores from the Bellingshausen abyssal plain and Antarctic continental rise (DSDP Leg 35). In Hollister, C. D., Craddock, C., et al., Init. Repts. DSDP, 35: Washington (U.S. Govt. Printing Office), 557-568.

Haq, B. U., Lohmann, G. P., and Wise, S. W., Jr., 1977. Calcareous nannoplankton biogeography and its paleoclimatic implications: Cenozoic of the Falkland Plateau (DSDP Leg 36) and Miocene of the Atlantic Ocean. In Barker, P. F., Dalziel, I. W. D., et al., Init. Repts. DSDP, 36: Washington (U.S. Govt. Printing Office), 745-760.

Haq, B. U., Premoli Silva, I., and Lohmann, G. P., 1977. Calcareous plankton biogeographic evidence for major climatic fluctuations in the Early Cenozoic Atlantic Ocean. J. Geophys. Res., 82: 3861-3876.

Hayes, D. E., and Frakes, L. A., 1975. General synthesis, Deep Sea Drilling Project Leg 28. In Hayes, D. E., Frakes, L. A., et al., Init. Repts. DSDP, 28: Washington (U.S. Govt. Printing Office): 919-942.

Hecht, A. D., and Savin, S. M., 1972. Phenotypic variation and oxygen isotope ratios in recent planktonic foraminifera. J. Foraminiferal Res., 2:55-67.

Hochuli, P. A., 1978. Palynologische Untersuchungen im Oligozän und Untermiozän der Zentralen und Westlichen Paratethys. Beitr. Palaontologie Oesterreich, Sonderdruck 4:1-132.

Keigwin, L. D., Jr., 1980. Oxygen and carbon isotope analyses from Eocene/Oligocene boundary at DSDP Site 277. Nature, 287: 722-725. 
Kemp, E. M., 1978. Tertiary climatic evolution and vegetation history in the Southeast Indian Ocean region. Palaeogeogr. Palaeoclimatol. Palaeoecol., 24:169-208.

1981. Tertiary paleogeography and the evolution of the Australian climate. In Keast, A. (Ed.), Ecological Biogeography of Australia: The Hague (Junk N. V. Publishers), pp. 33-49.

Kennett, J. P., 1977. Cenozoic evolution of Antarctic glaciation, the Circum-Antarctic Ocean, and their impact on global paleoceanography. J. Geophys. Res., 82:3843-3860.

, 1978. The development of planktonic biogeography in the Southern Ocean during the Cenozoic. Marine Micropaleontol., 3: 301-345.

Kroopnick, P., 1980a. The distribution of $\delta^{13} \mathrm{C}$ in the Atlantic Ocean. Earth Planet. Sci. Lett., 49:469-484.

, 1980b. Isotopic fractionations during oxygen consumption and carbonate dissolution within the North Atlantic Deep Water. Earth Planet. Sci. Lett., 49:485-498.

Luz, B., and Shackleton, N. J., 1975. $\mathrm{CaCO}_{3}$ solution in the tropical East Pacific during the past 130,000 years. Cushman Foundation Foraminiferal Res., Spec. Publ., 13:142-150.

McGowran, B., 1979. The Tertiary of Australia: foraminiferal overview. Marine Micropaleontol., 4:235-264.

Margolis, S. V., Kroopnick, P. M., Goodney, D. E., Dudley, W. C. and Mahoney, M. A., 1977. Cenozoic and Late Mesozoic paleoceanographic and paleoglacial history recorded in Circum-Antarctic deep-sea sediments. Geology, 25:131-147.

Perch-Nielsen, K., 1977. Albian to Pleistocene calcareous nannofossils from the western South Atlantic, DSDP Leg 39. In Supko, P. R., Perch-Nielsen, K., et al., Init. Repts. DSDP, 39: Washington (U.S. Govt. Printing Office), 699-823.

Savin, S. M., Douglas, R. G., and Stehi, F. G., 1975. Tertiary marine paleotemperatures. Geol. Soc. Am. Bull., 86:1499-1510.

Schwarzbach, M., 1974. Das Klima der Vorzeit. Eine Einführung in die Paläoklimatologie: Stuttgart (F. Enke).

Sclater, J. G., Hellinger, S., and Tapscott, C., 1977. The paleobathymetry of the Atlantic Ocean from the Jurassic to the present. $J$. Geol., 85:509-552.

Shackleton, N. J., 1977. Carbon-13 in Uvigerina: tropical rainforest history and the Equatorial Pacific carbonate dissolution cycles. In Andersen, N. R., and Malahoff, A. (Eds.), The Fate of Fossil Fuel $\mathrm{CO}_{2}$ in the Oceans. Marine Science 6: New York (Plenum), 401-427.
Shackleton, N. J., and Kennett, J. P., 1975a. Paleotemperature history of the Cenozoic and the initiation of Antarctic glaciation: oxygen and carbon isotope analyses in DSDP Sites 277, 279 and 281. In Kennett, J. P., Houtz, R. E., et al., Init. Repts. DSDP, 29: Washington (U.S. Govt. Printing Office), 743-755.

, 1975b. Late Cenozoic oxygen and carbon isotopic changes at DSDP Site 284: implications for glacial history of the Northern Hemisphere and Antarctic. In Kennett, J. P., Houtz, R. E., et al., Init. Repts. DSDP, 29: Washington (U.S. Govt. Printing Office), 801-808.

Simpson, E. S. W., Schlich, R., et al., 1974. Init. Repts. DSDP, 25 : Washington (U.S. Govt. Printing Office).

Toumarkine, M., 1978. Planktonic foraminiferal biostratigraphy of the Paleogene of Sites 360 to 364 and the Neogene of Sites 362A, 363, and 364 Leg 40. In Bolli, H. M., Ryan, W. B. F., et al., Init. Repts. DSDP, 40: Washington (U.S. Govt. Printing Office), 679-721.

Vergnaud Grazzini, C., Pierre, C., and Létolle, R., 1978. Paleoenvironment of the North-East Atlantic during the Cenozoic: oxygen and carbon isotope analyses at DSDP Sites 398, 400A and 401. Oceanol. Acta, 1:381-390.

Vergnaud Grazzini, C., and Rabussier Lointier, D., 1980. Compositions isotopiques de l'oxygène et du carbone des foraminifères tertiaires en Atlantique équatorial (site $366 \mathrm{du}$ DSDP). Rev. Géol. Dyn. Géogr. Phys., 22:63-74.

Vincent, E., Killingley, J. S., and Berger, W. H., 1981. Stable isotope composition of benthic foraminifera from the Equatorial Pacific. Nature, 289:639-643.

Volkheimer, W., 1971. Jurassic microflora and paleoclimates in Argentina. Proc. Second Gondwana Symp., Capetown and Johannesburg 1972, 543-549.

Weissel, J. K., Hayes, D. E., and Herron, E. M., 1977. Paleotectonic synthesis: The displacements between Australia, New Zealand and Antarctica since the Late Cretaceous. Marine Geol., 25:231-277.

Wolfe, J. A., 1972. An interpretation of Alaska Tertiary floras. In Graham, A. (Ed.), Floristic, Paleofloristics of Asia and Eastern N. America: Amsterdam (Elsevier), pp. 201-233.

Woodruff, F., Savin, S. M., and Douglas, R. G., 1980. Biological fractionation of oxygen and carbon isotopes by recent benthic foraminifera. Marine Micropaleontol., 5:3-11.

Date of Initial Receipt: August 3, 1982 